\title{
Ortaokul 6 ve 7. Sınıf Öğrencilerinin Bilimsel Epistemolojik İnanç Düzeyi ${ }^{1}$
}

\section{Middle School $6^{\text {th }}$ and $7^{\text {th }}$ Graders' Level of Scientific Epistemological Beliefs}

\begin{tabular}{|c|c|}
\hline & \\
\hline $\begin{array}{l}\text { Anahtar Kelimeler } \\
\text { Bilimsel } \\
\text { Epistemolojik inanç, } \\
\text { Ortaokul ögrencileri, } \\
\text { Bilimsel } \\
\text { Epistemolojik inanç } \\
\text { ölçeği, } \\
\text { Cinsiyet }\end{array}$ & 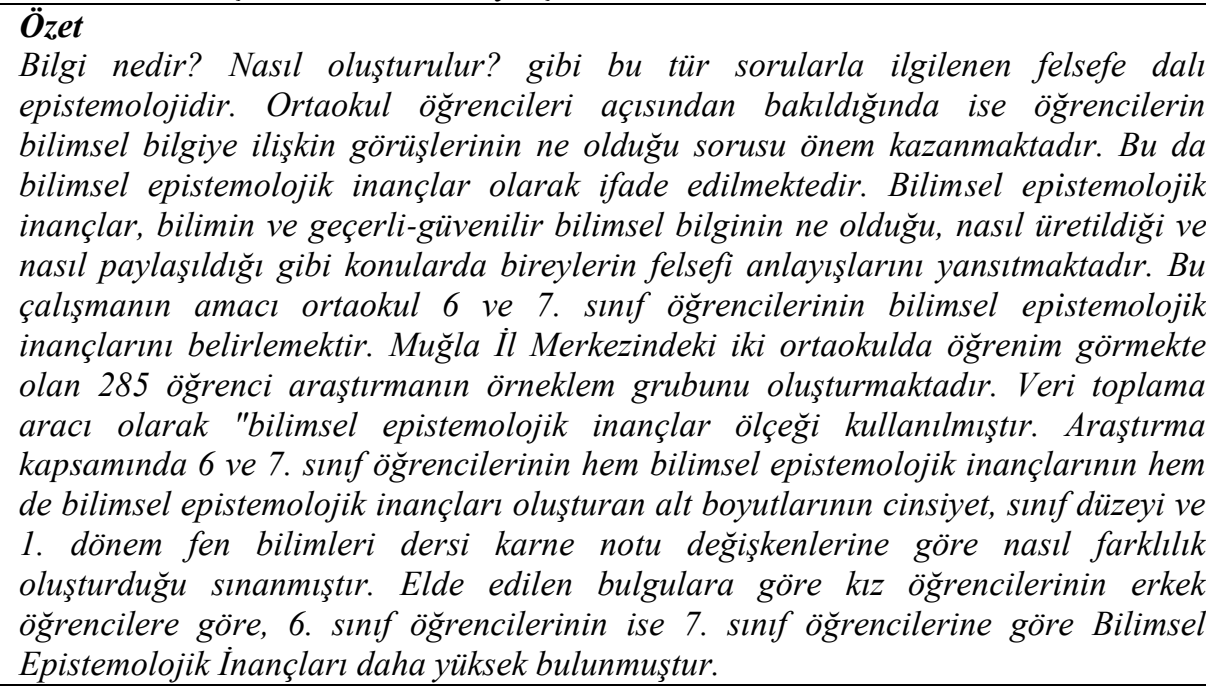 \\
\hline $\begin{array}{l}\text { Key Word } \\
\text { Scientific } \\
\text { Epistemological } \\
\text { belief, } \\
\text { Middle school } \\
\text { students, } \\
\text { Scientific } \\
\text { epistemological belief } \\
\text { scale, } \\
\text { Gender }\end{array}$ & $\begin{array}{l}\text { Abstract } \\
\text { The discipline of science interested in questions such as "What is knowledge?", } \\
\text { "How does it occur?" is epistemology. When this concept is examined in terms of } \\
\text { middle school students, it seems to be important to determine the opinions of these } \\
\text { students about the scientific knowledge. These opinions are expressed as scientific } \\
\text { epistemological beliefs. Scientific epistemological beliefs reflect individuals" } \\
\text { philosophical conceptions of the issues such as what is science and valid-reliable } \\
\text { scientific knowledge, how it is produced and how it is shared. The purpose of the } \\
\text { current study is to determine middle school 6th and 7th grade students' Scientific } \\
\text { Epistemological Beliefs. The sample of the study is comprised of } 285 \text { students } \\
\text { attending two different middle schools in the city of Mugla. As the data collection } \\
\text { tool, the "Scientific Epistemological Beliefs Scale" was used. In the current study, it } \\
\text { was investigated whether the middle school 6th and 7th grade students' scientific } \\
\text { epistemological beliefs and the sub-dimensions making up the scientific } \\
\text { epistemological beliefs vary significantly depending on gender, grade level and the } \\
\text { science grade point average in the school report of the first term. The obtained } \\
\text { findings have revealed that the scientific epistemological beliefs of the female } \\
\text { students are higher than those of the male students and the scientific epistemological } \\
\text { beliefs of the 6th grade students are higher than those of the 7th grade students. }\end{array}$ \\
\hline
\end{tabular}

Atıf için: $\quad$ Can, Ş., \& Çelik, C. (2020). Ortaokul 6 ve 7. sınıf öğrencilerinin bilimsel epistemolojik

For Citation İnanç düzeyi. Muğla Sitkı Koçman Üniversitesi Eğitim Fakültesi [MSKU Journal of Education], 7(2), 122-132. DOI: 10.21666/muefd.746092

Received: 12.06.2020 Accepted: 05.10.2020 $\quad$ Published: 01.11.2020

\footnotetext{
${ }^{1}$ Bu çalışma, II. Çă̆daş Ĕ̆itim Araştırmaları Kongresinde (2017) sözlü bildiri olarak sunulmuştur.

${ }^{2}$ Muğla Sitkı Koçman Üniversitesi Eğitim Fakültesi, csendil@mu.edu.tr. ORCID: 0000-0001-9313-7273

${ }^{3}$ Muğla Sitkı Koçman Üniversitesi Eğitim Fakültesi, cuneydcelik@mu.edu.tr. ORCID: 0000-0002-1188-6260
} 
Bilgi çağı olarak anılan içinde bulunduğumuz şu yüzyılda, insanın yaşamını kolaylaştırması ve teknolojik ilerlemeleri takip edebilmesi için, her an ilerleyen bilimsel ve teknolojik yeniliklere ayak uydurmak zorundadır. Bu ise toplumun değişim hızına yetişebilmesi için sorun çözen, sürekli yeniliğe açık, yaratıcı düşünebilen niteliklere sahip bireylerle mümkün olduğu düşünülmektedir. (Erdoğdu, 2006). Bu bağlamda eleştirel düşünebilen, bilişüstü farkındalığı olan, öz-düzenleme ve problem çözme becerileri güçlü bireylerin yetiştirilmesi ülkemiz öğretim programlarının hedefi olarak belirlendiği görülmüştür. Epistemolojik sorgulama, akıl (sezgi) ve deneyi sentezleyerek ortaya çıkan bilginin kaynağı; bilginin niteliğini irdeleyen bilimin doğası; bilginin olanaklı olup olmadığına yönelik yaklaşımlar barındıran bilginin imkânı temellerine dayanır (Aytaç, 2020). Bu temeller bireyin epistemolojik inancını oluşturur. İnançlar ise insanın bir olguya karşı tutumlarının temelini oluşturmaktadır. Bu tutumlara bağlı olarak bireylerin eylemleri ya da davranışları şekillenir. Bilginin ve bilgi edinmenin doğasına ilişkin inanışları tanımlayan epistemolojik inanç da insan zihninin düşünme becerisini şekillendirdiği düşünülmektedir (Pajares, 1992).

Schommer-Aikins, Duell ve Barker (2002) epistemolojik inanc1, bireyin bilgiyi ve bilginin öğrenilmesi ile ilgili inançları olarak tanımlamaktadır. Cano (2005) ve Tezci ve Uysal (2004) epistemolojiyi, bilgiyi araştıran ve insanın nasıl bildiğini inceleyen bir olgu olduğunu ifade etmiştir. $\mathrm{Bu}$ bağlamda bireyin epistemolojik anlayışı; bilginin ne olduğu, nasıl üretildiği, öğrenildiği ve öğretildiği konularını içermektedir. Yılmaz (2007)'ye göre epistemolojik inançlar, bireylerin kendi zihinlerinde oluşturdukları, bilginin özellikleri ve bilgiyi oluşturma süreçleri ile ilgili kanaatleri, düşünceleri ve yargılarını ifade eder. Diğer bir ifadeyle epistemolojik inanç, bireyin bilimin ne olduğuna, hangi süreçlerden geçerek oluştuğuna ve bilime karşı olan felsefi anlayışını yansıtmaktadır. Ayrıca Schommer vd. (2002), epistemolojik inançların sadece bilgiye yönelik inançları kapsamadığı bununla birlikte bireyin öğrenme süreci hakkındaki inançlarını da kapsadığını belirterek epistemolojik inanç kavramını genişletmiştir. Sandoval (2003) ise, epistemolojik inanç kavramına ilişkin öğrencilerin bilmesi gereken dört temel konu olduğunu belirlemiştir. Bu konuları; (1) Bilimsel Bilgi Yapılandırılır, (2) Bilimsel Yöntemlerin Farklılığı, (3) Bilimsel Bilgi Türleri, (4) Bilimsel Bilginin Kesinliği şekilde sıralamak mümkündür. Bu tanımları veya kavramsal çerçeveyi daha da genişletmek mümkündür. $\mathrm{Bu}$ yüzden epistemoloji kavramının tanımı üzerinde bilim insanlarının ortak bir fikirde toplanamadığı görülmüştür. (Sandavol, 2003). Bu sebepten dolayı literatürde epistemoloji kavramına ilişkin birçok tanım getirilmiştir. Eğitimin felsefi paradigmaları da epistemolojik inanç üzerine kurularak inşa edildiği ifade edilmektedir (Biçer, Er ve Özel, 2013; Kahramanoğlu ve Özbakış, 2018). Çünkü bu felsefi eğilimler, öğrenme stratelerini, öğretim tekniklerini, kullanılan materyalleri ve değerlendirme sürecini şekillendirmektedir (Duman, 2008; Duman ve Ulubey, 2008). Böylece epistemolojik inançların eğitim ve öğretimde, öğretme ve öğrenme sürecini yapılandırdığı söylenebilir (Uslu, 2018; Wong, Chan ve Lai, 2009).

İlgili literatür incelendiğinde epistemolojik inanç ile akademik başarı, öz-düzenleme, öğrenme yaklaşımları yaşamboyu öğrenme yeterlikleri, problem çözme becerileri ve üstbiliş arasında anlamlı bir ilişkinin olduğuna ilişkin birçok sonuç ile karşılaşılmaktadır (Başbay, 2013; Karataş, 2011; Kaya, 2018; Özkatar Kaya, 2018). Diğer bir ifade ile öğrenci, öğretmen adayı veya öğretmenin epistemolojik inanç düzeyi; akademik başarı, öz-düzenleme becerileri, yaşamboyu öğrenme yeterlikleri, öğrenme yaklaşımları ve üstbiliş gibi öğretme-öğrenme sürecini şekillendiren faktörler ile doğrudan ya da dolaylı etkileşim içerisinde olduğu söylenebilir. Gelişmiş epistemoloik inanca sahip öğrenciler; öğrenme sürecinde bilişsel bilgiyi işleme, bilişüstü farkındalık açısından öğretim materyallerini denetleme, akademik başarı sağlama, öğrenme ortamına yönelik olumlu tutum taşıma, karşılaştığı problemlerin çözümüne ilişkin girişimlerde bulunma ve çok yönlü fikir yürütme gibi özellikler taşımaktadır (Deryakulu ve Büyüköztürk, 2005; Schommer, 1994). Diğer taraftan 2018 Fen bilimleri öğretim programı kapsamında öğrencinin bilimsel bilginin bilim insanları tarafından nasıl oluşturulduğu, oluşturulan bu bilginin hangi süreçlerden geçtiğini, yeni araştırmalarda nasıl kullanıldığını fark etmesi ile öğrencide muhakeme yeteneği, bilimsel düşünme alışkanlığı ve karar verme becerilerinin geliştirilmesi, öğretim programının özel amaçları arasındadır (MEB, 2018). Bu bakımdan fen bilimleri öğretim programının bu hedefleri sağlanabilmesi için bireyde bilimsel epistemolojik anlayışın geliştirilmesi gerektiği söylenebilir.

Alan yazında yapılan araştırma sonuçları, epistemolojik inancın, öğrenme üzerinde önemli etkileri olduğunu göstermiştir. Evcim (2010)'in yapmış olduğu araştırma sonucuna göre fen bilimleri dersinde edinilen bilgilerin günlük yaşama aktarılma düzeyi ile epistemolojik inanç düzeyi arasında yüksek 
düzeyde ilişki ortaya çıkmıştır. Bu bağlamda epistemolojik inancın, bilimsel bilginin anlamlı bir şekilde öğrenilmesini ve bu bilginin kullanılmasını sağladığı söylenebilir. Hofer (1994), üniversite 1. sınıf öğrencileri üzerinde gerçekleştirdiği araştırmada epistemolojik inancı daha yüksek öğrencilerin öz-denetimlerinin daha nitelikli olduğunu, bununla birlikte epistemolojik inancı yüksek olan öğrencilerin aktif öğrenme, işbirliği içinde çalışma, problem çözme ve matematik dersinde grafik hesap makinelerinin kullanımı becerilerinin daha yüksek olduğu sonucuna ulaşmıştır. Cano (2005), 1600 ortaokul öğrencisi üzerinde yürüttüğü araştırmasında epistemolojik inancın öğrencilerin akademik başarılarını doğrudan etkilediğini, bununla birlikte öğrencilerin akademik performanslarını da dolaylı olarak olumlu yönde etkilediği sonucuna ulaşmıştır. Bu araştırmalar dışında ülkemiz literatüründe epistemolojik inançlar konusuna ilişkin lisansüstü öğrencileriyle (Izgar ve Dilmaç, 2008), öğretmenlerle (Yılmaz, 2007), öğretmen adayları ile (Deryakulu ve Büyüköztürk, 2005; Eroğlu ve Güven, 2006; Meral ve Çolak, 2009; Oksal, Şenşekerci ve Bilgin, 2006; Terzi, 2005), ilkokul ve ortaokul öğrencileriyle (Balantekin, 2013; Demir ve Doğanay, 2009; Kurt, 2009; Sadıç ve Çam, 2015; Topçu ve Yılmaz-Tüzün, 2009; Yeşilyurt, 2013) çalışılmıştır.

Epistemolojik inancın öğrencilerin akademik başarıları ve performansları üzerine yaptığı doğrudan veya dolaylı katkı göz önüne alındığında öğrencilerin mevcut bilimsel epistemolojik inançlarının hangi durumda olduğu önem arz etmektedir. Bu bağlamda araştırmanın amacı, ortaokul 6 ve 7. sınıf öğrencilerinin bilimsel epistemolojik inançlarını çeşitli değiş̧kenler açısından tespit etmektir. Bu amaç doğrultusunda şu sorulara yanıt aranmıştır:

1. Ortaokul 6 ve 7. sınıf öğrencilerin bilimsel epistemolojik inançları hangi düzeydedir?

2. Ortaokul 6 ve 7. sınıf öğrencilerinin bilimsel epistemolojik inançları, cinsiyet değişkenine göre anlamlı farkl111k göstermekte midir?

3. Ortaokul 6 ve 7. sınıf öğrencilerinin bilimsel epistemolojik inançları, sınıf düzeyi değişkenine göre anlamlı farklılık göstermekte midir?

4. Ortaokul 6 ve 7. sınıf öğrencilerinin bilimsel epistemolojik inançları, fen bilimleri dersi karne notu değişkenine göre anlamlı farklılık göstermekte midir?

\section{Yöntem}

$\mathrm{Bu}$ araştırma tarama modeliyle yürütülmüş̧ür. Tarama desenli araştırmalar, bir evren içerisinden seçilen bir örneklem üzerinde yapılan çalışmalar yoluyla evren genelindeki eğilim, tutum veya görüşlerin sayısal olarak betimlenmesini sağlamaktadır (Creswell, 2013).

\section{Örneklem}

Araştırmanın evreni Muğla ilinde öğrenim gören 6 ve 7. sınıf öğrencilerinden; örneklem ise uygun örnekleme yöntemi ile Muğla İli merkezinde yer alan iki ortaokulda 143 altıncı sınıf ve 142 yedinci sınıf olmak üzere toplam 285 öğrenciden oluşmaktadır. Araştırmanın örneklemini oluşturan katılımcıların dağılımına ilişkin detaylı bilgi Tablo 1 'de gösterilmiştir.

Tablo 1

Katılımcıların Sinıf ve Cinsiyete Göre Dağılımı

\begin{tabular}{lcccccc}
\hline Sinıf Düzeyi & \multicolumn{2}{c}{ Kiz } & \multicolumn{2}{c}{ Erkek } & \multicolumn{2}{c}{ Toplam } \\
\hline & $\boldsymbol{n}$ & $\boldsymbol{\%}$ & $\boldsymbol{n}$ & $\boldsymbol{\%}$ & $\boldsymbol{n}$ & $\boldsymbol{\%}$ \\
6. Sinıf & 71 & 24,91 & 72 & 25,26 & 143 & 50,17 \\
7. Sinıf & 78 & 27,37 & 64 & 22,46 & 138 & 49,83 \\
\hline
\end{tabular}

\section{Veri Toplama Araci}

Araştırmada veri toplama aracı olarak, ortaokul öğrencilerinin bilimsel bilgiye ilişkin inançlarını belirlemek amaciyla Elder (1999) tarafından geliştirilip Acat, Tüken ve Karadağ (2010) tarafindan Türkçeye uyarlanan "Bilimsel Epistemolojik İnançlar Ölçeği" kullanılmıştır. Bilimsel Epistemolojik İnançlar Ölçeği, 25 maddeden oluşan 5'li likert tipinde (Kesinlikle Katılmıyorum, Katılmıyorum, Kararsızım, Katılıyorum, Kesinlikle Katılıyorum) hazırlanmış ve 5 faktörden oluşan bir yapıya sahip bir ölçme aracıdır. Ölçeğin alt boyutları Otorite ve Doğruluk, Bilgi Üretme Süreci, Bilginin Kaynağı, Akıl Yürütme, Bilginin Değişirliği şeklindedir. Acat vd. (2010), ölçeğin güvenirlik katsayılarını Otorite ve Doğruluk için 0.86, Bilgi Üretme Süreci için 0.68, Bilginin Kaynağ için 0.70, Akü 
Yürütme için 0.62, Bilginin Değişirliği için 0.57 ve ölçeğin bütünü için ise 0.82 olarak hesaplamıştır. Mevcut araştırmada ise ölçeğin güvenirlik katsayıları, Otorite ve Doğruluk için 0.86, Bilgi Üretme Süreci için 0.70, Bilginin Kaynağı için 0.69, Akıl Yürütme için 0.57, Bilginin Değişirliği için 0.55 ve ölçeğin bütünü için ise 0.86 olarak hesaplanmıştır. Mevcut araştırma da hesaplanan Cronbach alpha iç tutarlılık katsayısı, ölçeğin güvenilir ve tutarlı bir yapıya sahip olduğunu göstermektedir (Fraenkel, WaIlen ve Hyun, 2012). Hem Acat vd. (2010) tarafindan hesaplanan hem de mevcut araştırma sırasında elde edilen güvenirlilik katsayıları Tablo 2'de gösterilmiştir.

Tablo 2

Ölçeğin Alt Boyutlarına İlişkin Güvenirlik Katsayıları

\begin{tabular}{|c|c|c|c|c|}
\hline \multirow[b]{2}{*}{ Boyutlar } & \multicolumn{2}{|c|}{$\begin{array}{c}\text { Acat, Tüken } \\
\text { ve Karadağ (2010) }\end{array}$} & \multicolumn{2}{|c|}{ Mevcut araştırma } \\
\hline & $\mathbf{n}$ & $\begin{array}{c}\text { Güvenirlik } \\
\text { Katsayısı }\end{array}$ & $\mathbf{n}$ & $\begin{array}{c}\text { Güvenirlik } \\
\text { Katsayısı }\end{array}$ \\
\hline Otorite ve Doğruluk & 212 & 86 & 285 & 86 \\
\hline Bilgi Üretme Süreci & 212 & 68 & 285 & 70 \\
\hline Bilginin Kaynağ 1 & 212 & ,70 & 285 & 69 \\
\hline Akıl Yürütme & 212 & ,62 & 285 &, 57 \\
\hline Bilginin Değişirliği & 212 &, 57 & 285 & ,55 \\
\hline Ölçeğin Geneli & 212 & 82 & 285 &, 80 \\
\hline
\end{tabular}

Bilimsel epistemolojik İnançları Ölçeğinde bir katılımcı en düşük 25 puan en yüksek ise 125 puan alabilmektedir. Bu puan aralığı Otorite ve Doğruluk boyutu için 9 ile 45 puan; Bilgi Üretme Süreci boyutu için 6 ile 30 puan; Bilginin Kaynağı boyutu için 4 ile 20 puan; Akıl Yürütme boyutu için 4 ile 20 puan ve Bilginin Değişirliği boyutu de 4 ile 20 puan arasında değişmektedir. Ancak Otorite ve Doğruluk ve Bilginin Kaynağı boyutlarının tamamı olumsuz anlam taşıyan maddelerdir.

\section{Verilerin Analizi}

Verilerin analizinde SPSS 21.0 paket programı kullanılmıştır. Mevcut araştırmada elde edilen verilerin normal dağılım gösterip göstermediği çarpıklık ve basıklık katsayısı dikkate alınarak belirlenmiştir. Buna göre mevcut veriler üzerinde yapılan normallik analizlerinde Çarpıklık katsayısı $0,354 \pm(0,144)$; Basıklık katsayısı ise $-0,102 \pm(0,287)$ olarak hesaplanmıştır. Bu değerlerin, +1 ile -1 arasında olması, dağılımın normalden fazla sapmadığının göstergesi olarak kabul edilmektedir (Çokluk, Şekercioğlu ve Büyüköztürk, 2012). Dolayısıyla verilerin analizinde parametrik istatistik yöntemler kullanılmıştır. Veri toplama aracının otorite ve doğruluk ile bilginin kaynă̆ oluştuğu için analiz yapılmadan önce ters kodlanmıştır. Araştırma kapsamında hem bilimsel epistemolojik inançların hem de bilimsel epistemolojik inançları oluşturan her bir alt boyutların hangi düzeyde olduğu, betimsel istatistik ile; cinsiyet, sınıf düzeyi değişkenlerine göre nasıl farklılık oluşturduğu Bağımsız gruplar için t-testi ile; 1. dönem fen bilimleri dersi karne notu değişkenlerine göre anlamlı farklılık oluşturup oluşturmadığı Tek Yönlü Varyans Analizi ile test edilmiştir.

\section{Bulgular}

\section{Katılımcıların Bilimsel Epistemolojik İnançları Düzeyi}

Araştırmaya katılan öğrencilerin hem Bilimsel Epistemolojik İnançlarının, hem de alt boyutlara ilişkin inanç düzeylerinin belirlenmesinde betimsel istatistik kullanılmıştır. Analiz sonuçlarına ilişkin bulgular Tablo 3 'te gösterilmiştir.

Tablo 3'e göre katılımcıların bilimsel epistemolojik inanç düzeyi ortalaması 3,40 olarak hesaplanmıştır. Diğer taraftan bilimsel epistemolojik inancın otorite ve doğruluk boyutuna ilişkin ortalama 2,42; bilgi üretme süreci boyutuna ilişkin ortalama 3,89; bilginin kaynağ ortalama 2,85; akıl yürütme boyutuna ilişkin ortalama 4,10 ve bilginin değişirliği boyutuna ilişkin ortalama ise 3,78 olarak hesaplanmıştır. Bu değerlere bakılarak 6 ve 7. sınıf öğrencilerin otorite ve doğruluk ve bilginin kaynă̆ 
edilmiştir. Diğer taraftan bilgi üretme süreci, bilginin değişirliği ve akıl yürütme boyutları ise genel ortalamanın (Ort: 3,40$)$ oldukça üzerinde yer aldığı belirlenmiştir.

Tablo 3

Katılımcıların Bilimsel Epistemolojik Inançları ve Alt Boyutlarına İlişkin Puanlar

\begin{tabular}{lcccc}
\hline \multicolumn{1}{c}{ Boyutlar } & $\mathbf{n}$ & Madde Sayıs & $\overline{\mathbf{x}}$ & Ss \\
\hline Otorite ve Doğruluk & 285 & 9 & 2,42 & 0,91 \\
Bilgi Üretme Süreci & 285 & 6 & 3,89 & 0,73 \\
Bilginin Kaynağı & 285 & 4 & 2,85 & 0,93 \\
Ak1l Yürütme & 285 & 3 & 4,10 & 0,74 \\
Bilginin Değişirliği & 285 & 3 & 3,78 & 0,76 \\
\hline Bilimsel Epistemolojik İnançları & 285 & 25 & 3,40 & 0,47 \\
\hline
\end{tabular}

\section{Katılımcıların Cinsiyete Göre Bilimsel Epistemolojik İnançları}

Öğrencilerin bilimsel epistemolojik inanç ve alt boyutların cinsiyet değişkeninin etkisi olup olmadığı bağımsız gruplar t testi ile analiz edilmiş ve bulgular Tablo 4'te gösterilmiştir.

Tablo 4

Öğrencilerin Bilimsel Epistemolojik İnanç ve Alt Boyutlara İlişkin Puanlarının Cinsiyete Göre T-Testi Sonuçları

\begin{tabular}{lccccccc}
\hline \multicolumn{1}{c}{ Boyutlar } & Cinsiyet & $\mathbf{n}$ & $\overline{\mathbf{x}}$ & $\mathbf{S s}$ & $\mathbf{t}$ & $\mathbf{s d}$ & $\mathbf{p}$ \\
\hline Otorite ve & Kız & 149 & 2.37 & .88 & $-0,825$ & 283 &, 41 \\
Doğruluk & Erkek & 136 & 2.46 & .93 & & & \\
Bilgi Üretme & Kız & 149 & 3.99 & .68 & 2,688 & 283 &, 00 \\
Süreci & Erkek & 136 & 3.77 & .75 & & & \\
Bilginin & Kız & 149 & 2.82 & .87 & $-0,581$ & 283 &, 56 \\
Kaynağı & Erkek & 136 & 2.88 & .99 & & & \\
Akıl Yürütme & Kız & 149 & 4.18 & .64 & 1,971 & 283 &, 04 \\
Bilginin & Erkek & 136 & 4.01 & .83 & & & \\
Değişebilirliği & Kız & 149 & 3.80 & .74 & 0,394 & 283 &, 69 \\
Bilimsel & Krkek & 136 & 3.76 & .77 & & & \\
Epistemolojik & Erkek & 149 & 3.42 & .44 & 1,007 & 283 &, 53 \\
İnanç & 136 & 3.37 & .51 & & & \\
\hline
\end{tabular}

Tablo 4'te, kız öğrencilerin bilimsel epistemolojik inançlarının erkeklere göre daha yüksek olmasına rağmen bilimsel epistemolojik inanç, cinsiyet değişkenine göre anlamlı bir farklılık oluşturmamıştır $[\mathrm{t}(283)=0.623, \mathrm{p}>0,05]$. Bunun yanında Bilgi Üretme Süreci ve Akll Yürütme alt boyutlarında cinsiyet değiş̧kenine göre anlamlı farklılık görülmektedir [t(283)=2,688, p<0,05], $[\mathrm{t}(283)=1,971, \mathrm{p}<0,05]$. Bilgi Üretme Süreci alt boyutuna ilişkin kız öğrencilerin ortalaması 3,99 iken erkek öğrencilerin 3,77 dir. Akal Yürütme alt boyutuna ilişkin olarak ise kız öğrencilerin ortalaması 4,18 iken erkek öğrencilerin 4,01'dir.

Diğer taraftan Otorite ve Doğruluk, Bilginin Kaynağı ve Bilginin Değişebilirliği alt boyutlarında ise cinsiyet değişkenine göre anlamlı farklılık görülmemiştir [t(283) $=-0,825, \mathrm{p}>0,05],[\mathrm{t}(283)=-0,581$, $\mathrm{p}>0,05],[\mathrm{t}(283)=0,394, \mathrm{p}>0,05]$.

\section{Katılımcıların Sınıf Düzeylerine göre Bilimsel Epistemolojik İnançları}

Öğrencilerin bilimsel epistemolojik inanç ve alt boyutların sınıf düzeyine göre bir farklılık oluşturup oluşturmadığı bağımsız gruplar t-testi ile analiz edilmiştir. Analiz sonuçlarına ilişkin bulgular Tablo 5 'te sunulmuştur. 
Tablo 5

Öğrencilerin Bilimsel Epistemolojik İnanç ve Alt Boyutlara İlişkin Puanlarının Sınıf Düzeyine Göre T- Testi Sonuçları

\begin{tabular}{|c|c|c|c|c|c|c|c|}
\hline Boyutlar & Grup & $\mathbf{n}$ & $\overline{\mathbf{x}}$ & Ss & sd & $\mathbf{t}$ & $\mathbf{p}$ \\
\hline \multirow{2}{*}{$\begin{array}{l}\text { Otorite } \\
\text { Doğruluk }\end{array}$} & 6. Sinif & 143 & 2,45 & 0,90 & 283 & 0,49 & 62 \\
\hline & 7. Sinif & 142 & 2,40 & 0,93 & & & \\
\hline \multirow{2}{*}{$\begin{array}{l}\text { Bilgi } \\
\text { Süreci }\end{array}$} & 6. Sinıf & 143 & 3,97 & 0,74 & 283 & 1,79 & ,07 \\
\hline & 7. Sinıf & 142 & 3,82 & 0,68 & & & \\
\hline \multirow{2}{*}{$\begin{array}{l}\text { Bilginin } \\
\text { Kaynağ } 1\end{array}$} & 6. Sinif & 143 & 2,83 & 0,97 & 283 & $-0,49$ & ,62 \\
\hline & 7. Sinıf & 142 & 2,88 & 0,89 & & & \\
\hline \multirow{2}{*}{ Akıl Yürütme } & 6. Sinıf & 143 & 4,13 & 0,70 & 283 & 0,72 & ,47 \\
\hline & 7. Sinıf & 142 & 4,07 & 0,78 & & & \\
\hline \multirow{2}{*}{$\begin{array}{l}\text { Bilginin } \\
\text { Değiş̧ebilirliği }\end{array}$} & 6. Sinıf & 143 & 3,81 & 0,79 & 283 & 0,68 &, 50 \\
\hline & 7. Sinif & 142 & 3,74 & 0,72 & & & \\
\hline \multirow{2}{*}{$\begin{array}{l}\text { Bilimsel } \\
\text { Epistemolojik } \\
\text { İnanç }\end{array}$} & 6. Sinif & 143 & 3,23 & 0,51 & 283 & 1,05 & ,30 \\
\hline & 7. Sinif & 142 & 3,18 & 0,50 & & & \\
\hline
\end{tabular}

Tablo 5 incelendiğinde 6 ve 7. sınıf öğrencilerin hem bilimsel epistemolojik inanç düzeyi [t(283) = $1,05, \mathrm{p}>0,05]$ hem de bilimsel epistemolojik inançları oluşturan boyutlar, sınıf düzeyine göre anlamlı bir farklılık oluşturmadığ görülmüştür [t(283)=0,49, p>0,05], [t(283)=1,79, p>0,05], [t(283)=-0,49, $\mathrm{p}>0,05],[\mathrm{t}(283)=0,72, \mathrm{p}>0,05],[\mathrm{t}(283)=0,68, \mathrm{p}>0,05]$. Bu durumun nedeni, 6 ve 7. sinıf öğrencilerin öğretim düzeyleri arasında, bilimsel epistemolojik inancın kayda değer gelişim göstermesi için yeterli zaman diliminin olmamasından kaynaklanabilir. Ancak 6. Sınıf öğrencilerin epistemolojik inanç düzeyi, 7. Sınıf öğrencilerine göre daha yüksek olması araştırmada dikkat çeken bulgular arasındadır.

\section{Katılımcıların Fen Bilimleri Dersi Karne Notuna Göre Bilimsel Epistemolojik İnançları}

Ortaokul 6 ve 7. sınıf öğrencilerinin Bilimsel Epistemolojik inançlarının öğrencilerin fen bilimleri karne notuna göre bir farklılık oluşturup oluşturmadığ 1 tek yönlü varyans analizi ile tespit edilmiştir. ANOVA'nm uygulanacağı örneklemde varyansların homojenliği varsayımı levene testi yapılarak sınanmıştır. Levene testinden elde edilen bulguya göre verilerin homojenlik varsayımını sağladığı belirlenmiştir.

Tablo 6

Katılımcıların Karne Notlarına Göre Bilimsel Epistemolojik Inanç ve Alt Faktör Puanları

\begin{tabular}{|c|c|c|c|c|}
\hline $\begin{array}{c}\text { Bilimsel } \\
\text { Epistemolojik } \\
\text { İnanç Ölçeği }\end{array}$ & Karne Notu & $\mathbf{n}$ & $\overline{\mathbf{x}}$ & $\mathbf{S}$ \\
\hline \multirow{3}{*}{ Otorite ve Doğruluk } & 3 (Orta) & 18 & 2.67 & .92 \\
\hline & 4 (İyi) & 56 & 2.63 & .88 \\
\hline & 5 (Pekiyi) & 211 & 2.33 & .90 \\
\hline \multirow{4}{*}{ Bilgi Üretme Süreci } & 3 (Orta) & 18 & 3.52 & .80 \\
\hline & 4 (İyi) & 56 & 3.70 & .74 \\
\hline & 5 (Pekiyi) & 211 & 3.96 & .69 \\
\hline & 3 (Orta) & 18 & 2.83 & 1.04 \\
\hline \multirow[t]{2}{*}{ Bilginin Kaynağı } & 4 (İyi) & 56 & 2.96 & .83 \\
\hline & 5 (Pekiyi) & 211 & 2.81 & .94 \\
\hline \multirow{3}{*}{ Ak1l Yürütme } & 3 (Orta) & 18 & 3.66 & .90 \\
\hline & 4 (İyi) & 56 & 4.01 & .72 \\
\hline & 5 (Pekiyi) & 211 & 4.16 & .71 \\
\hline \multirow{3}{*}{$\begin{array}{l}\text { Bilginin } \\
\text { Değişebilirliği }\end{array}$} & 3 (Orta) & 18 & 3.62 & .83 \\
\hline & 4 (İvi) & 56 & 3.63 & .74 \\
\hline & 5 (Pekivi) & 211 & 3.83 & .75 \\
\hline \multirow{3}{*}{$\begin{array}{l}\text { Bilimsel } \\
\text { Epistemolojik İnanç }\end{array}$} & 3 (Orta) & 18 & 3.27 & .59 \\
\hline & 4 (İyi) & 56 & 3.39 & .50 \\
\hline & 5 (Pekivi) & 211 & 3.42 & .46 \\
\hline
\end{tabular}


Tablo 6'da ortaokul 6 ve 7. sınıf öğrencilerin bilimsel epistemolojik inanç düzeyleri fen bilimleri dersi karne notuna göre gösterimi bulunmaktadır. Buna göre; Otorite ve doğruluk ve Bilginin Kaynağ boyutlarına ilişkin inanç, fen bilimleri dersi akademik başarısı yükseldikçe azaldığ görülmektedir. Diğer taraftan Bilgi Üretme Süreci, Akıl Yürütme ve Bilginin Değişirliği boyutlarına ilişkin inanç ise fen bilimleri dersi akademik başarısı yükseldikçe yükseldiği görülmektedir. Ölçeğin geneli için değerlendirildiğinde ise karne notu arttıkça öğrencilerin bilimsel epistemolojik inançlarında artış gösterdiği söylenebilir.

Tablo 7 incelendiğinde bilimsel epistemolojik inançları oluşturan boyutlardan bazıları, öğrencilerin fen bilimleri karne notuna göre farklılık gösterdiği belirlenmiştir. Bu fark sadece Otorite ve Doğruluk $[\mathrm{F}(2-283)=9,883, \mathrm{p}<0,05]$; Bilgi Üretme Süreci $[\mathrm{F}(2-283)=3,980, \mathrm{p}<0,05]$ ve Akll Yürütme $[\mathrm{F}(2-$ $283)=3,728, p<0,05]$ boyutlarında ortaya çıkmıştır. Başka bir ifade ile ortaokul 6 ve 7 . sınıf ögrencilerin bilimsel epistemolojik inançları, fen bilimleri dersi karne notuna bağlı olarak değiştiği söylenebilir. Karne notları arasındaki farkın hangi gruplar arasında olduğunu belirlemek amacıyla Scheffe testi yapılmıştır. Bu sonuca göre, Bilgi Üretme Süreci $(\overline{\mathrm{x}}=3,96)$ ve Akıl Yürütme $(\overline{\mathrm{x}}=4,16)$ boyutlarına ilişkin bilimsel epistemolojik inanç düzeyi, fen bilimleri dersi karne notu 5 olan öğrenci grubu lehine farklılaşırken; Otorite ve Doğruluk $(\overline{\mathrm{x}}=2,67)$, boyutuna ilişkin bilimsel epistemolojik inanç düzeyi, fen bilimleri dersi karne notu 3 olan öğrenci grubu lehine olduğu belirlenmiştir.

Tablo 7.

Katılımcıların Fen Bilimleri Dersi Karne Notuna Göre Bilimsel Epistemolojik İnançlarına İlişkin ANOVA Sonuçları

\begin{tabular}{|c|c|c|c|c|c|c|c|}
\hline $\begin{array}{c}\text { Bilimsel } \\
\text { Epistemoloji } \\
\text { k İnanç } \\
\text { Ölçeği }\end{array}$ & & $\begin{array}{c}\text { Karelerin } \\
\text { Toplamı }\end{array}$ & $\begin{array}{c}\text { Serbestlik } \\
\text { Derecesi }\end{array}$ & $\begin{array}{c}\text { Ortalamal } \\
\text { armn } \\
\text { Karesi }\end{array}$ & $\mathrm{F}$ & $\mathbf{p}$ & $\begin{array}{c}\text { Anlamlı } \\
\text { Fark }\end{array}$ \\
\hline \multirow{4}{*}{$\begin{array}{l}\text { Otorite ve } \\
\text { Doğruluk }\end{array}$} & Gruplar & & 2 & 2,70 & 3,33 & ,03 & 3-5 \\
\hline & Arasi & 5,41 & & & & & $4-5$ \\
\hline & Grup İçi & 229,26 & 283 &, 81 & & & \\
\hline & Toplam & 234,67 & 285 & & & & \\
\hline \multirow{4}{*}{$\begin{array}{l}\text { Bilgi Üretme } \\
\text { Süreci }\end{array}$} & Gruplar & 558 & 2 & 2,79 & 5,46 & ,00 & $3-5$ \\
\hline & Aras1 & 5,38 & & & & & \\
\hline & Grup İçi & 144,52 & 283 &, 51 & & & \\
\hline & Toplam & 150,10 & 285 & & & & \\
\hline \multirow{3}{*}{$\begin{array}{l}\text { Bilginin } \\
\text { Kaynağ1 }\end{array}$} & Gruplar & 1,03 & 2 &, 52 &, 59 &, 55 & - \\
\hline & Grup İçi & 245,28 & 283 & 87 & & & \\
\hline & Toplam & 246,31 & 285 & & & & \\
\hline \multirow{3}{*}{ Akı1 Yürütme } & $\begin{array}{l}\text { Gruplar } \\
\text { Aras1 }\end{array}$ & 4,60 & 2 & 2,31 & 4,31 & ,01 & $3-5$ \\
\hline & Grup İçi & 151,10 & 283 &, 53 & & & \\
\hline & Toplam & 155,70 & 285 & & & & \\
\hline \multirow{3}{*}{$\begin{array}{l}\text { Bilginin } \\
\text { Değişebilirliği }\end{array}$} & Gruplar & 2,03 & 2 & 1,02 & 1,79 & ,17 & - \\
\hline & Grup İçi & 160,98 & 283 &, 57 & \multirow{5}{*}{,93 } & \multirow{5}{*}{, 37} & \\
\hline & Toplam & 163,01 & 285 & & & & \\
\hline \multirow{3}{*}{$\begin{array}{l}\text { Bilimsel } \\
\text { Epistemolojik } \\
\text { İnanç }\end{array}$} & Gruplar & ,42 & 2 & ,21 & & & - \\
\hline & $\begin{array}{l}\text { Aras1 } \\
\text { Grup İçi }\end{array}$ & 63,71 & 283 & ,23 & & & \\
\hline & Toplam & 64,13 & 285 & & & & \\
\hline
\end{tabular}

\section{Tartışma ve Sonuç}

$\mathrm{Bu}$ araştırmada ortaokul 6 ve 7. sınıf öğrencilerinin Bilimsel Epistemolojik İnançlarının düzeyi otorite ve doğruluk, bilgi üretme süreci, bilginin kaynă̆l, akıl yürütme ve bilginin değişirliği boyutlarında değerlendirilmiş̧ir. Bununla birlikte bilimsel epistemolojik inancın öğrenim görülen sınıf, cinsiyet ve fen bilimleri ders karne notu değişkenleri açısından tespit edilmiştir. Ortaokul öğrencilerinin bilimsel epistemolojik inancın akıl yürütme boyutu en yüksek, otorite ve doğruluk boyutu ise en düşük düzeye sahip olduğu görülmüştür. 
Bilimsel epistemolojik inancı oluşturan boyutlar kendi içerisinde ayrı ayrı değerlendirilmiştir. Rubba ve Andersen (1978) ve Roth ve Roychoudhry (1994)' ye göre otorite ve doğruluk, bilimsel bilginin kesin olduğuna ve otoriteden geldiğine inanılır. Bununla birlikte, bilimsel bilgi kaynağı, eğer otorite sahibi ise kesinlikle doğru olduğunu ifade eder. Bu bağlamda otorite ve doğruluk boyutuna ilişkin ortalama puanının düşük olması bilginin kaynağının güvenilir olup olmadığından ziyade bilgiyi söyleyen otoriteye inanıldığını göstermektedir. Buradan hareketle araştırma bulguları incelendiğinde bilimsel bilgiden ziyade o bilgiye ilişkin alanında tanınmış kişinin söylemlerine dikkat edildiği söylenebilir.

Akerson, Abd-El-Khalick ve Lederman, (2000) ve Osborne, Collins, Ratcliffe, Millar ve Duschl, (2003)'a göre bilgi üretme süreci, empirik kökenli deneyimlere bağlıdır. Bilimsel bilginin oluşturulmasında deneyin rolüne, gerekçelendirilmesi sürecine değer verilir. Araştırma bulgularına dayanarak bu boyuta ilişkin ortalama, kabul edilebilir düzeyde olduğu söylenebilir. Rubba ve Andersen (1978) ve Ryan ve Aikenhead, (1992)'a göre kitap ve öğretmenlerin her söylediği bilimsel bilginin doğru olmadığını, eğer kişinin bilimsel bilginin kaynağını kitap/öğretmen gibi figürlerde araması, gelişmemiş epistemolojik inançlara karşılık geldiğini ifade etmiştir. Diğer bir ifade ile bu boyuta ilişkin ortalamanın düşük çıkması, bireyin bilginin kaynağı olarak çevresinde bulunan kişiler olarak gördüğü anlamına gelmektedir. Diğer bir ifade ile epistemolojik inancının tam olarak olgunlaşmadığının göstergesi olduğu kabul edilmektedir. Araştırmadan elde edilen bulgulara dayanarak 6 ve 7. sınıf öğrencileri, çevresinde bulunan kitapları ve öğretmenleri bilimsel bilginin kesin ve doğru kaynağı olduğuna inanmaktadır. Bu durumun sebebi olarak öğrencilerin kitap veya öğretmenlerin kendilerini yanlış bilgi ile bilgilendirmeyeceğine olan güvenlerinden kaynaklandığı düşünülmektedir.

Osborne, Collins, Ratcliffe, Millar ve Duschl, (2003) ve NRC, (2007)'ye göre bilimsel bilginin ilk çıkış1 mevcut bilgilerden yola çıkarak insanoğlunun yeni bilgilere ulaşmak istemesindeki merakına, gözlemlerine ve mantığına dayalı olarak oluşur. Bu boyut, bireylerin çağdaş bilim anlayışına ne kadar bağlı olduğunu ve bilginin oluşumundaki merak ve sorgulama boyutuna ne ölçüde inandıklarını ele almaktadır (Acat, Tüken ve Karadağ, 2010). Araştırmadan elde edilen bulgular 1şı̆̆ında öğrencilerin bilimsel epistemolojik inancın akıl yürütme boyutuna ilişkin düzeylerinin yüksek olduğu söylenebilir.

NRC (2007) ve Osborne, Collins, vd. (2003)'a göre bilimsel bilginin kesin ve değişmez olmadığını, bilim insanlarının gözlem, deney ve teorik yoluyla yapılan açıklamalarında doğa ile uyuşmayan ya da anlaşmazlıkların meydana gelmesi durumunda yeni deneysel kanıtlar çerçevesinde mevcut görüşlerinin yerini başkalarıyla değiştirirler. Diğer bir ifade ile, bu boyut bireylerin bilimsel bilginin sabit ya da değişen doğasına ne ölçüde inandıklarını ortaya koymaktadır (Rubba ve Andersen, 1978). $\mathrm{Bu}$ bilgiler ışı̆̆ında araştırma sonuçlarına dayanarak 6 ve 7 . sınıf öğrencilerinin bilginin değişebilirliğine ilişkin inançları, kabul edilebilir düzeyde olduğu söylenebilir.

Araştırmada, bilimsel epistemolojik inancı oluşturan boyutlar cinsiyet değişkenine göre incelendiğinde, kız öğrencilerin bilgi üretme süreci ve akıl yürütme boyutlarında erkeklere göre daha olgunlaştığı söylenebilir. Alan yazın incelendiğinde Yeşilyurt (2013)'da bilgi üretme süreci ve akıl yürütme boyutlarında kız öğrencilerin erkek öğrencilere göre daha yüksek inanç düzeyine sahip olduğu sonucuna ulaşmıştır. Bu sonuç mevcut araştırma sonucuyla örtüşmektedir. Balantekin (2013) ise ortaokul 6, 7 ve 8. sınıf 304 öğrencinin bilimsel bilgiye yönelik görüşlerini belirlediği araştırma da sadece Bilimsel Bilgi Gerekçelendirilir faktöründe kız öğrenciler lehine anlamlı fark saptamıştır. Bunun dışında kalan faktörlerde cinsiyet değişkeni, öğrencilerin bilimsel bilgiye yönelik görüşlerini etkilemediği sonucuna ulaşılmıştır. Yine Topçu ve Tüzün (2009), ilköğretim kız öğrencilerinin erkek öğrencilere göre daha gelişmiş epistemolojik inançlara sahip olduğunu saptanmıştır. Çocukların ergenlik dönemine girmesiyle birlikte soyut düşünmeye başladığı bununla birlikte kız çocuklarının erkek çocuklarına göre daha erken, ergenlik dönemine girdiği bilinmektedir (Senemoğlu, 2005). Buradan hareketle, bilimsel epistemolojik inançların bazı faktörlerinde kız öğrenciler lehine anlamlı farkın meydana gelmesi, kız öğrencilerin daha erken, ergenlik dönemine girmelerinden kaynaklandığı düşünülmektedir. Ancak alan yazında farklı araştırma sonuçlarına da rastlanılmaktadır. Mevcut araştırma ile aynı ölçme aracının kullanıldığı bir başka araştırma sonucuna göre Başer Gülsoy, Erol ve Akbay (2015), 5 ve 6. sınıf öğrencilerinin bilimsel epistemolojik inanç düzeyinin tüm boyutlar için cinsiyet değiş̧kenine bağlı olmadığ 1 sonucuna ulaşmıştır. Yine Aydın ve Geçici (2017), ortaokul ögrencilerinin epistemolojik inanç düzeyleri cinsiyet değişkenine göre farkl1l1k göstermediği sonucuna ulaşmıştır. 
Ortaokul öğrencilerinin öğrenim gördüğü sınıf düzeyi, onların bilimsel epistemolojik inancı zerinde bir etkisinin olmadığı sonucuna ulaşılmıştır. Bu sonucun nedeni olarak 6 ve 7. sınıf öğrencilerin öğretim düzeyleri arasında, bilimsel epistemolojik inancın kayda değer gelişim göstermesi açısından kısa bir zaman olduğu düşünülmektedir. Ancak 6. sınıf öğrencilerinin epistemolojik inanç düzeyi, 7. sınıf öğrencilerine göre daha yüksek olması araştırmanın dikkat çeken bulguları arasındadır. Alan yazın incelendiğinde Başer vd. (2015), 5 ve 6. sınıf düzeyinde öğrenim gören öğrencilerle yürüttüğü çalışma mevcut araştırma bulguları ile paralellik göstermektedir. Yine aynı araştırmada 5. sınıf öğrencilerinin bilimsel epistemolojik inanç düzeyi 6. sınıf öğrencilerine göre daha yüksek olduğu görülmüştür. Yine Yeşilyurt (2013), 7 ve 8 . sınıf öğrencileriyle yürüttüğü araştırmada da sınıf düzeyi arttıkça öğrencilerin epistemolojik inançlarında bir artışın olmadığ 1 sonucuna ulaşmıştır.

Araştırmada elde edilen bir diğer sonuca göre akademik başarı, bilimsel epistemolojik inancı oluşturan otorite ve doğruluk, bilgi üretme süreci ve akıl yürütme boyutları üzerinde etkili olurken bilginin kaynă̆ ve bilginin değişirliği boyutları üzerinde etkili değildir. Alan yazın incelendiğinde Aydın ve Geçici (2017), akademik başarı düzeyi daha yüksek olan öğrencilerin epistemolojik inanç (Bilginin kaynağı ve gerekçelendirme) düzeyleri üzerine olumlu etkiler sağladığı sonucuna ulaşmıştır. Yine Yeşilyurt (2013), otorite ve doğruluk ile bilginin kaynağı boyutlarında en gelişmiş inanç (negatif inanç) düzeyine akademik yönden zayıf olan öğrenci grubunun; akıl yürütme ile bilginin değişirliği boyutlarında ise en gelişmiş inanç düzeyi ise akademik başarı yönünden iyi olan öğrencilerin sahip olduğu sonucuna ulaşmıştır. Bu sonucun mevcut araştırma bulgularıyla örtüştüğü görülmüştür. $\mathrm{Bu}$ durumun nedeni fen bilimleri dersinde başarılı kabul edilen öğrencilerin sofistik inançlarının daha gelişmiş olmasına (Conley, Pintrich Vekiri ve Harrison, 2004) ya da akademik başarı yönünden yeterli olan öğrencilerin bilimsel epistemolojik inançları diğer öğrencilere göre daha esnek ve gelişmeye açık olmasına dayandırılabilir (Yeşilyurt, 2013; Yılmaz, 2007). Araştırmadan elde edilen bulgulara dayanarak şu öneriler getirilmiştir:

a) Bilimsel epistemolojik inancın bağlı olduğu başka değişkenler ortaya çıkarılabilir.

b) Özellikle bilimsel epistemolojik inancın zayıf kalan bazı boyutları dikkate alınarak, öğrencilerin bilimsel epistemolojik inançlarının geliştirilmesine katkı sağlayabilecek etkinlikler, çeşitli dersler kapsamında gerçekleştirilebilir.

\section{Kaynakça}

Acat, M. B., Tüken, G., \& Karadağ, E. (2010). Bilimsel epistemolojik inançlar ölçeği: Türk kültürüne uyarlama, dil geçerliği ve faktör yapısının incelenmesi. Journal of Turkish Science Education, 7(4), 67-89.

Akerson, V. L., Abd-El-Khalick, F., \& Lederman, N. G. (2000). Influence of a reflective explicit activity-based approach on elementary teachers' conceptions of nature of science. Journal of Research in Science Teaching, 37(4), 295-317.

Aydın, M., \& Geçici, M. E. (2017). 6. sınıf öğrencilerinin epistemolojik inançlarının bazı değişkenler açısından incelenmesi. Ahi Evran Üniversitesi Kırşehir Eğitim Fakültesi Dergisi (KEFAD), $18(1), 213-229$.

Aytaç, A. (2020). Öğretmen adaylarinin epistemolojik inançlarinin ve eğitim felsefesi ĕgilimlerinin ögretme ve ögrenme anlayişlari üzerindeki etkisi. Yayınlanmamış Doktora tezi. Balıkesir Üniversitesi Sosyal Bilimler Enstitüsü.

Balatekin, Y. (2013). İlköğretim öğrencilerinin bilimsel bilgiye yönelik epistemolojik inançları. Bartın Üniversitesi Ë̆itim Fakültesi Dergisi, 2(2), 312-328.

Başbay, M. (2013). Epistemolojik inancın eleştirel düşünme ve üstbiliş ile ilişkisinin yapısal eşitlik modeli ile incelenmesi. Ë̆itim ve Bilim, 38(169), 249-262.

Başer Gülsoy, V. G., Erol, O., \& Akbay, T. (2015). Ortaokul öğrencilerinin bilimsel epistemolojik inançlarının farklı değişkenlere göre incelenmesi. Mehmet Akif Ersoy Üniversitesi Eğitim Fakültesi Dergisi, 35, 1-28.

Biçer, B., Er, H., \& Özel A. (2013). Öğretmen adaylarının epistemolojik inançları ve benimsedikleri eğitim felsefeleri arasındaki ilişki. Ë̆itimde Kuram ve Uygulama, 9(3), 229-242.

Cano, F. (2005). Epistemological beliefs and approaches to learning: Their change through secondary school and their influence on academic performance. British Journal of Educational Psychology, 75, 203-221. 
Conley, A. M., Pintrich, R. P., Vekiri, I., \& Harrison, D. (2004). Changes in epistemological beliefs in elementary science students. Contemporary Educational Psychology, 29, 186-204.

Çokluk, Ö., Şekercioğlu, G., \& Büyüköztürk, Ş. (2012). Sosyal bilimler için çok değişkenli istatistik SPSS ve LISREL uygulamaları (2. Bask1). Ankara: Pegem Akademi.

Deryakulu, D., \& Büyüköztürk, Ş., (2005). Epistemolojik inanç ölçeği’nin faktör yapısının incelenmesi: Cinsiyet ve ögrenim görülen program türüne göre epistemolojik inançların karş1laştırılması. Ĕ̈itim Araştırmaları Dergisi, 18, 57-70.

Duman, B., \& Ulubey, Ö. (2008). Öğretmen adaylarının benimsedikleri eğitim felsefelerinin öğretim teknolojilerini ve interneti kullanma düzeylerine etkisi ile ilgili görüşleri. Muğla Üniversitesi Sosyal Bilimler Enstitüsü Dergisi, 20, 95-114.

Duman, B. (2008). Öğrencilerin benimsedikleri eğitim felsefeleriyle kullanıldıkları öğrenme strateji ve öğrenme stillerinin karşılaştırılması. Çukurova Üniversitesi Sosyal Bilimler Enstitüsü Dergisi, 17(1), 203-224.

Erdoğdu, Y. M. (2006). Yaratıcılık değerlendirme ölçeğinin türk kültürüne uyarlanması. İnönü Üniversitesi Eğitim Fakültesi Dergisi, 7(12), 61-79.

Eroğlu, S. E., \& Güven, K. (2006). Üniversite öğrencilerinin epistemolojik inançlarının bazı değişkenler açısından incelenmesi. Selçuk Üniversitesi Sosyal Bilimler Enstitüsü Dergisi, 16, 295-313.

Fraenkel, J. R., Wallen, N. E., \& Hyun, H. H. (2012). How to design and evaluate research in education (8. Bask1). New York: McGraw-Hill.

Hofer, B. (1994). Epistemological beliefs and first-year college students: motivation and cognition in different instructional contexts. Paper presented at the annual meeting of the American Psychological Association, Los Angeles.

Izgar, H., \& Dilmaç, B. (2008). Yönetici adayı öğretmenlerin öz-yeterlik algıları ve epistemolojik inançlarının incelenmesi. Selçuk Üniversitesi Sosyal Bilimler Enstitüsü Dergisi, 20, 437-446.

Kahramanoğlu, R., \& Özbakış, G. (2018). Sınıf öğretmenlerinin eğitim inançlarının ve epistemolojik inançlarının belirlenmesi. Disiplinlerarası Eğitim Araştırmaları Dergisi, 2(3), 8-27.

Karataş, H. (2011). Üniversite ögrrencilerinin epistemolojik inançları, öğrenme yaklaşımları ve problem çözme becerilerinin akademik motivasyonu yordama gücü. Yayımlanmamıs Doktora Tezi. İstanbul: Yıldız Teknik Üniversitesi Sosyal Bilimler Enstitüsü.

Kaya, K. (2018). Öğretmenlerin bilimsel epistemolojik inançlart ile yaşam boyu ögrrenme yeterlikleri arasındaki ilişki. Yayımlanmamış Yüksek Lisans Tezi. Van Yüzüncü Yıl Üniversitesi Eğitim Bilimleri Enstitüsü.

Meral, M., \& Çolak, E. (2009). Öğretmen adaylarının bilimsel epistemolojik inançlarının incelenmesi. Ondokuz Mayıs Üniversitesi Ĕ̈itim Fakültesi Dergisi. 27, 129-146.

Oksal, A., Şenşekerci, E., \& Bilgin, A. (2006). Merkezi epistemolojik inançlar ölçeğinin geliştirilmesi: Geçerlik ve güvenirlik. Uludă̆ Üniversitesi Eğitim Fakültesi Dergisi, 19(2), 371-381.

Osborne, J., Collins, S., Ratcliffe, M., Millar, R., \& Duschl, R. (2003). What 'ideas-about-science' should be taught in school science? A Delphi study of the expert community. Journal of Research in Science Teaching, 40(7), 692-720.

Özkatar Kaya, E. (2018). Beden eğitimi ögretmeni adaylarının epistemolojik inançları, akademik özdüzenleme ve öz-yeterlilik düzeyleri arasındaki ilişkinin incelenmesi. Yayımlanmamış Doktora Tezi. Erciyes Üniversitesi Sağlık Bilimleri Enstitüsü.

Pajares, M. F. (1992). Teachers' beliefs and educational research: Cleaning up a messay construct. Review of Educational Research, 62 (3), 307-332.

Reiser, B., Duschl, R. A. (Ed.), Schweingruber, H. A. (Ed.), \& Shouse, A. W. (Ed.) (2007). Taking science to school: Learning and teaching science in grades $K-8$. Committee on Science Learning, Kindergarten through 8th grade: National Research Council, Board on Science Education, Division of Behavioral and Social Sciences and Education. The National Academies Press.

Roth, W. M., \& Roychoudhury, A. (1994). Physics students' epistemologies and views about knowing and learning. Journal of Research in Science Teaching, 31(1), 5-30.

Rubba, P. A., \& Andersen, H. (1978). Development of an instrument to assess secondary school students ${ }^{\text {'e }}$ understanding of the nature of scientific knowledge. Science Education, 62(4), 449458. 
Ryan, A. G., \& Aikenhead, G., S.(1992). Students' preconceptions about the epistemology of science. Science Education, 76(6), 559-580

Sandoval, W. A. (2003). The inquiry paradox: why doing science doesn't necessarily change ideas about science. Computer-Based Learning in Science Conference Proceedings of the Sixth Intl.. 825-834.

Schommer-Aikins, M., Duell, K. O., \& Barker, S. (2002). Epistemological belief across domains using biglan's classification of academic disciplines. Research Higher Education, 44(3), 346-366.

Senemoğlu, N. (2005). Kuramdan uygulamaya gelişim, ögrenme ve öğretim, Gazi Kitapevi, Ankara.

Terzi, A.R., (2005). Üniversite öğrencilerinin bilimsel epistemolojik inançları üzerine bir araştırma. Afyon Kocatepe Üniversitesi Sosyal Bilimler Enstitüsü Dergisi. 7(2). 298-311.

Tezci, E., \& Uysal, A. (2004). Eğitim teknolojisinin gelişimine epistemolojik yaklaşımların etkisi. The Turkish Online Journal of Educational Technology, 3(2), 158-164.

Topçu, M. S., \& Yılmaz-Tüzün, Ö. (2009). Elementary students' metacognition and epistemological beliefs considering science achievement, gender and socioeconomic status. Elementary Education Online, 8(3), 676-693.

Uslu, Ö. (2018). Analysis of variables that affect teaching learning approaches and epistemological beliefs of pre-service teachers by structural equation model. International Journal of Research in Education and Science (IJRES), 4 (1), 237-251. DOİ: 10.21890/ijres.383167 (Erişim Tarihi: 10.09.2019).

Wong, A.K., Chan K., \& Lai, P. (2009). Revisiting the relationship epistemological beliefs and conceptions about teaching and learning of pre-service teachers in Hong Kong. The Asia-Pasific Education Researchers, 18(1), 1-19.

Yeşilyurt, E. (2013). İlköğretim okulu öğrencilerinin bilimsel epistemolojik inançları. The Journal of Academic Social Science Studies, 6(1), 1587-1609.

Y1lmaz, A. (2007). Hemşirelik öğrencilerinin epistemolojik inançları ile denetim odağı arasındaki ilişki. Yayınlanmamış Yüksek Lisans Tezi, İstanbul Üniversitesi, İstanbul.

Y1lmaz, K. (2007). Öğrencilerin epistemolojik ve matematik problemi çözümlerine yönelik inançlarının problem çözme sürecine etkisinin araştırılması. Yayımlanmamış Yüksek Lisans Tezi, Marmara Üniversitesi Eğitim Bilimleri Enstitüsü. 